\title{
OBSERVATIONS \\ ON THE QUATERNARY FIRN LINE IN PERU
}

\author{
By J. Trigart \\ (Centre de Géographie Appliquée, Université de Strasbourg, France)
}

\begin{abstract}
At lat. $7^{\circ} \mathrm{S}$. the firn line was at about $3,500 \mathrm{~m}$. during the Riss glaciation, at $3,650 \mathrm{~m}$. during the Würm maximum and at $3,700 \mathrm{~m}$. during a later stage (Würm II?). The moraines were deposited by equatorial-type glaciers from which there was relatively little melt water.

At lat. $14^{\circ} \mathrm{S}$., during the Riss glaciation, an important ice cap covered a 3,900-4,000 m. high plateau, the firn line being at about $3,950 \mathrm{~m}$. The role of melt waters was important in the formation of the moraines, suggesting their deposition from tropical-type glaciers. From the evidence of periglacial gravels it appears that this southern region has not been glaciated since Riss times.
\end{abstract}

RÉsumé. Observations de la ligne des neiges du Pérou au Quaternaire. A la latitude $7^{\circ} \mathrm{S}$, la ligne des neiges se situait à environ $3500 \mathrm{~m}$ pendant la glaciation de Riss, à $3650 \mathrm{~m}$ au maximum du Wurm, et à $3700 \mathrm{~m}$ à une époque ultérieure (Wurm II ?). Les moraines ont été déposées par des glaciers de type équatorial à faible débit d'eau de fonte.

A la latitude $14^{\circ} \mathrm{S}$, pendant la glaciation de Riss, une calotte de glace importante recouvrait à $3900-$ $4000 \mathrm{~m}$ un haut plateau; la ligne des neiges se trouvait à environ $3950 \mathrm{~m}$. Les eaux de fonte durent jouer un rôle important dans la formation des moraines et leur dépôt semble provenir de glaciers de type tropical. Des graviers périglaciaires montrent que cette région méridionale n’a pas été englacée depuis la période de Riss.

Zusammenfassung. Beobachtungen zur quartären Schneegrenze in Peru. Auf $7^{\circ}$ südl. Breite lag die Schneegrenze während der Riss-Eiszeit in $3500 \mathrm{~m}$ Höhe, während des Würm-Maximums in $3650 \mathrm{~m}$ und während eines späteren Stadiums (Würm II?) in $3700 \mathrm{~m}$. Die Moränen wurden von Gletschern des äquatorialen Typs abgelagert, die relativ wenig Schmelzwasser lieferten.

Auf 14 südl. Breite bedeckte während der Riss-Eiszeit eine mächtige Eiskappe ein Hochplateau in 3900-4000 m Höhe, wobei die Schneegrenze auf etwa $3950 \mathrm{~m}$ lag. Bei der Bildung der Moränen spielte das Schmelzwasser eine wichtige Rolle, was ihre Ablagerung durch Gletscher vom tropischen Typ annehmen lässt. Das Auftreten periglazialen Gruses ist ein Zeichen dafür, dass dieses südliche Gebiet seit der Riss-Zeit nicht mehr vergletschert war.

DURING the course of research into problems of agricultural management in 1963 , an opportunity arose to undertake surveys in two of the scientifically least-known areas of the Peruvian Andes. One of these surveys was carried out in the vicinity of Hualgayoc and San Miguel de Pallaques, between Cajamarca and Chota (Fig. I), in the northern Andes; the other was between Nazca and Puquio (Fig. I), approximately midway between Lima and Arequipa. Both surveys revealed Quaternary glacial phenomena which enabled the firn line of that time to be determined.

\section{The Cajamarca - Chota Area}

The observations were made in the vicinity of lat. $7^{\circ} \mathrm{S}$., on a large slightly dissected plateau formed of calcareous sediments (Fig. 2), which is the watershed between the Atlantic and Pacific Oceans. The sediments are simply folded in the northern part of the area studied but they have been strongly jointed and fractured by intrusions, veins, dykes and volcanic vents; to the east the latter are the source of important eruptions. These igneous rocks indicate locally the origin of the detrital material and they have been useful in the positive identification of the moraines.

A wide valley opens out above Hualgayoc, which is on the eastern side of the plateau, and the approach to this mining village passes through a deep gorge cut down through the edge of the escarpment, which is formed by a monocline (Figs. 3 and 4 ). Influenced by a transverse feature, the valley has a typical U-shape. No definite moraines were observed down-stream but only characteristic periglacial formations: graded screes composed of debris from the congelifraction of limestones, the smaller-sized fragments of which are $5 \mathrm{~cm}$. These are best 
developed on the south-facing slopes, which have been completely smoothed by them, because they conceal projections formed by beds less fissile than those on the north-facing slopes and are not affected by the localized superficial deposits. Such asymmetry can be explained by the fact that this south-facing hillslope is in the Southern Hemisphere; this is the equivalent of a northern slope in the Northern Hemisphere. At a height of $3,45^{\circ} \mathrm{m}$. these graded screes are isolated and poorly developed but at $3,500 \mathrm{~m}$. they are more widespread. They could be dated as Würm. In this particular case, if the valley had been eroded by a glacier, as its shape indicates, it would be much older (probably Riss) and the terminal moraines deposited at the entrance to the gorge would have been eroded.

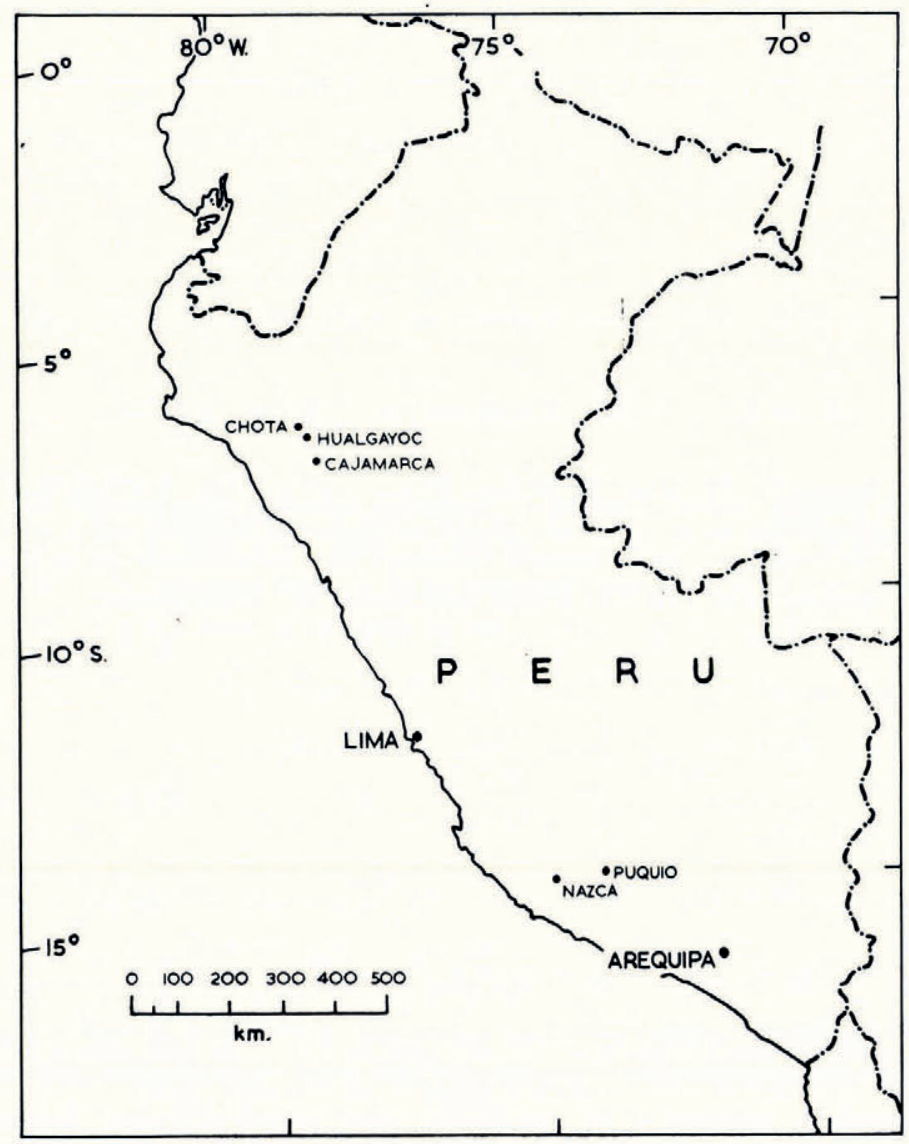

Fig. I. Map of Peru showing the location of the areas investigated

This valley widens up-stream into a spacious amphitheatre which is not a true cirque. Down-stream it terminates at a small bench cut into a ridge of the typical moraines, which are rich in allothogenic blocks of a granular intrusive rock. The matrix of this moraine has not been eroded away, which is indicative of the small amount of melt water. Having described the nature and situation of the area, it is suggested that this moraine was deposited at the extremity of a cirque glacier (at $3,620 \mathrm{~m}$.) close to the firn line. The freshness of the material which has been reduced slightly by congelifraction due to the mildness of subsequent periglacial activity, is indicative of a Würm age for the moraine. 


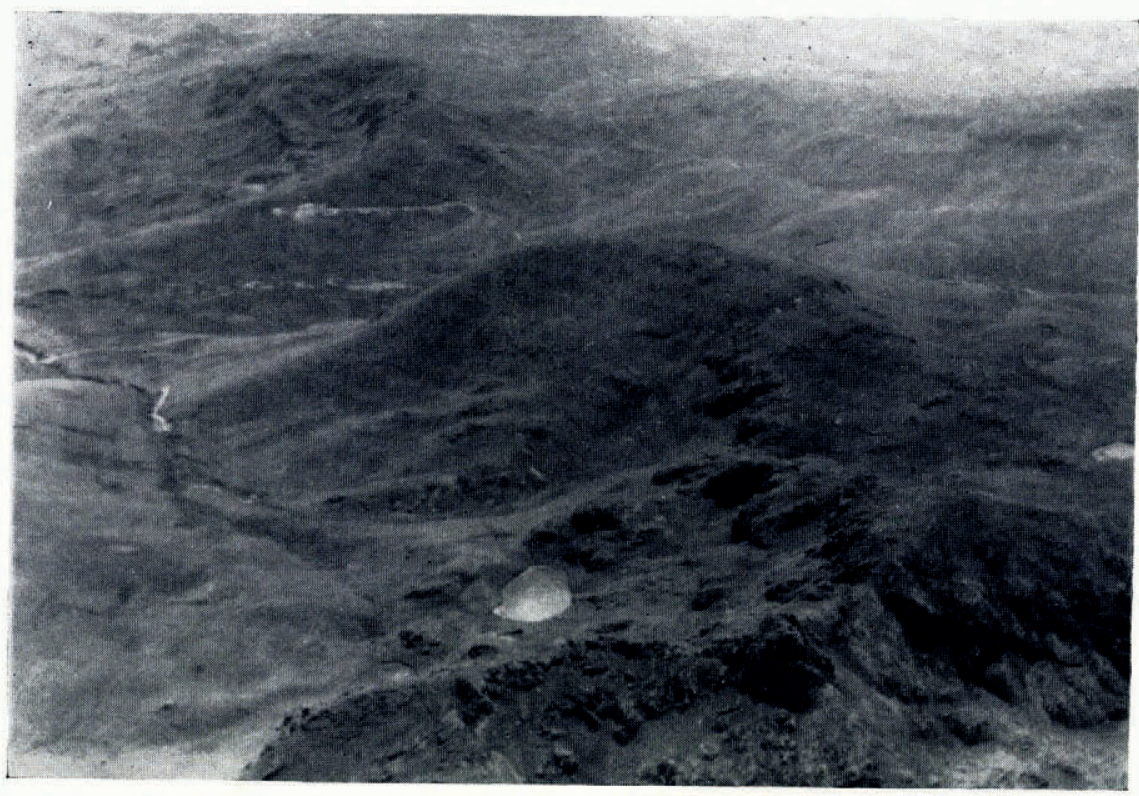

Fig. 2. Würm glacial surface relief to the west of Chota, at about $4,000 \mathrm{~m}$. on the calcareous plateau. The photograph shows ridges cut by cirques, a small lake, roches moutonnées and moraines

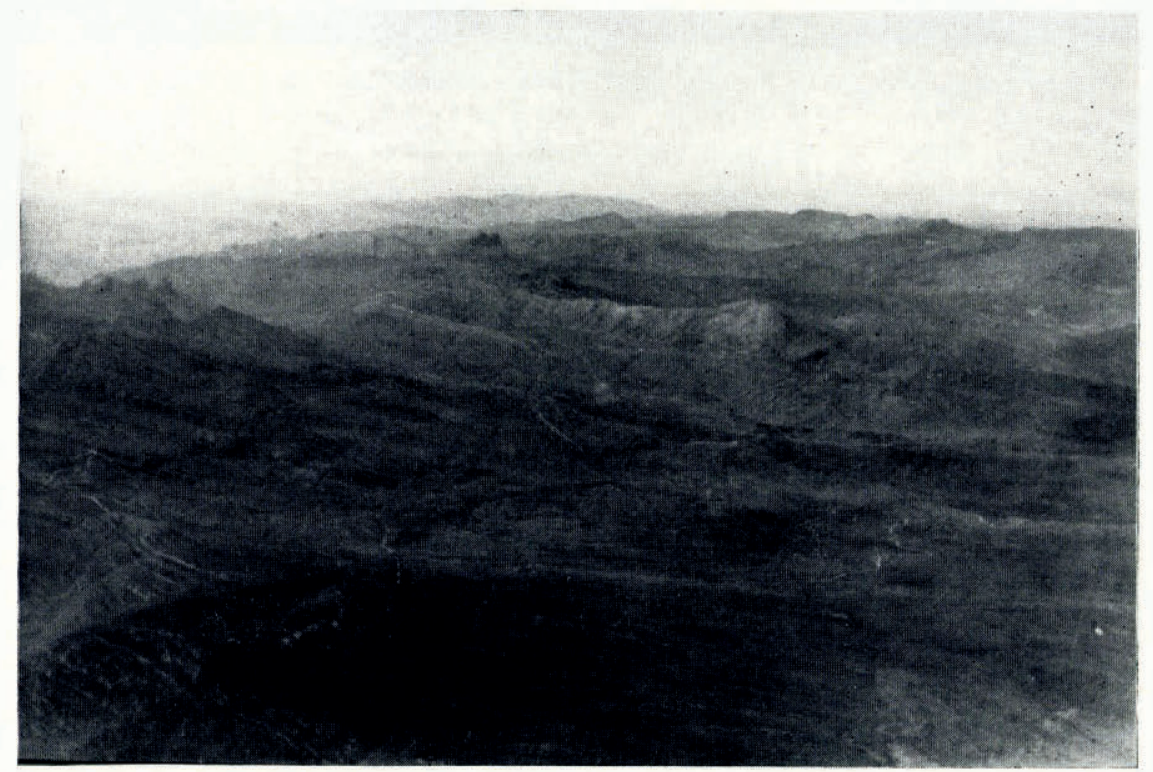

Fig. 3. The calcareous plafeau affected by the Würm glaciation north-west of Hualgayoc. The highest monoclines are at $4,300 \mathrm{~m}$.; there is evidence of erosion by ice and there are lakes and moraines in the depressions 
However, in the amphitheatre which marks the exit, a small cirque has clearly been excavated in an intrusion of granular rocks. The bottom of the cirque shows polishing by ice (roche moutonnée) which is still fresh. This cirque which terminates at 3,700 $\mathrm{m}$. was formed at a late stage of the Würm, whereas the moraine at 3,620 m. corresponds to the maximum of this glacial period, i.e. Würm I.

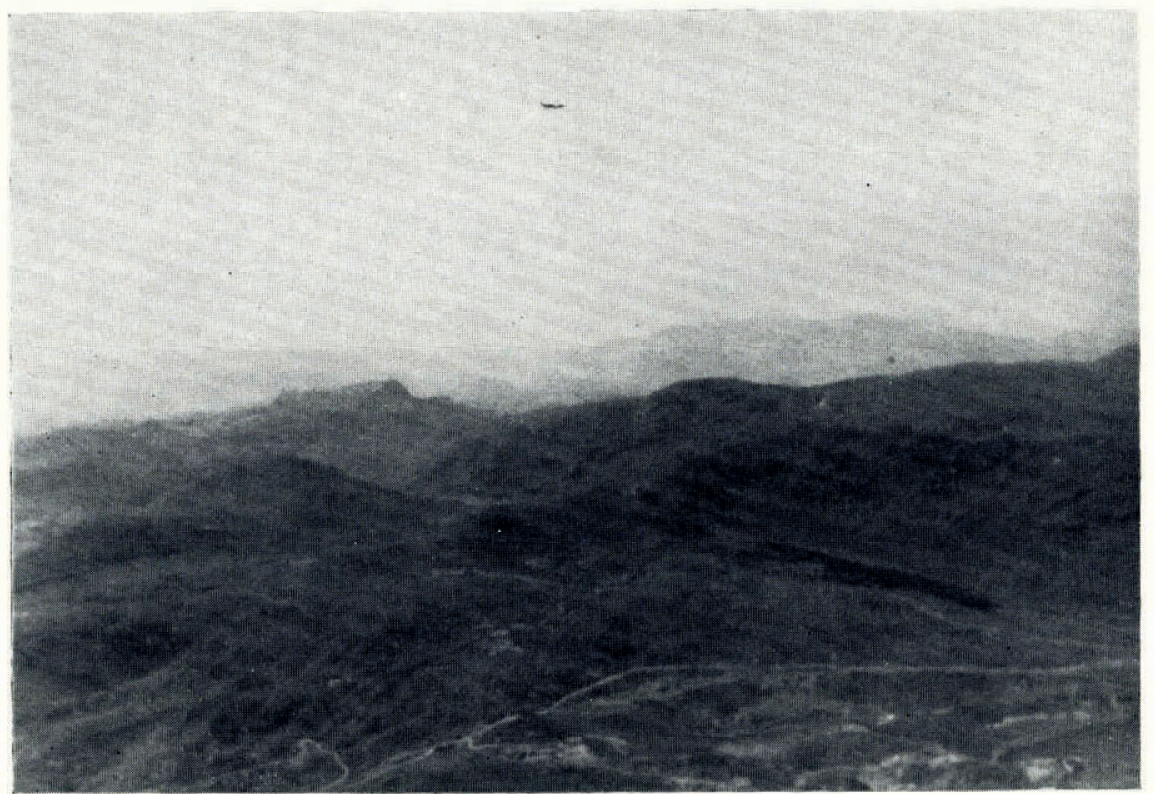

Fig. 4. The same calcareous plateau as in Figure 3 viewed from a lower altitude. The cirques are very clearly shown

A little farther to the east, the high plateau forms an escarpment dominating a large valley whose bottom is at $3,400 \mathrm{~m}$. No moraines have been observed here. In contrast, at $3,870 \mathrm{~m}$. on the escarpment, a series of small nivation hollows has been eroded in the limestone and, more particularly, in the granular intrusive rocks. At their foot they are distinguished by accumulations of fine material (gravels and sands) in well-defined but very thin layers. These are the products of erosion by melt water from the névé.

Still farther east, on a large plateau forming the other side of this monoclinal escarpment, there is a large $(2 \mathrm{~km}$. in diameter) marshy basin on the limestones which appears to be an ancient polje. At one time it was occupied by ice which came from the south-west and left several successive ridges of terminal moraine, three of which are very clear and occur between 3,700 and $3,750 \mathrm{~m}$. They have been subsequently cut through by melt waters, and behind the latest of the moraines there is a very small fluvio-glacial terrace which indicates a short lacustrine period prior to this dissection. A little farther south, a second eastward-moving glacier tongue occupied a nearby basin. Its extremity is indicated by two excellent lateral moraines forming projecting tongues at $3,600 \mathrm{~m}$.

\section{The Nazca - Puquio Area}

Evidence of glaciation on a large plateau, forming the continental watershed and situated a little south of lat. $14^{\circ} \mathrm{S}$., is described in this section. The plateau is composed of a complex of volcanic eruptions; flows and plugs of resistant lava form small hills (mesas, dykes and 
necks) and dominate the relief which is vaguely conical, while less resistant scoria and tuff beds are also present. The relief of the plateau at about $4,000 \mathrm{~m}$. is much less marked than that near Hualgayoc. The wide but ill-defined valleys, where Ichu grass flourishes, are separated by minor interfluves which are only $50 \mathrm{~m}$. high. The highest points are the sharp but fairly steep peaks; they are always isolated from one another and at the most form only an ill-defined range. Rejuvenation of erosion has not reached as far as this area, having stopped farther down-stream at the edge of the plateau in the beds of resistant lavas, where gorges cut into the rock often resemble saw cuts. Such topographic features have no effect whatsoever. If the firn line were at the level of the plateau, it would be hidden by an ice cap with a slow rate of outflow. If the firn line were a little higher, the sharp peaks would have insufficient surface to allow either glaciers or any form of glaciation to develop.

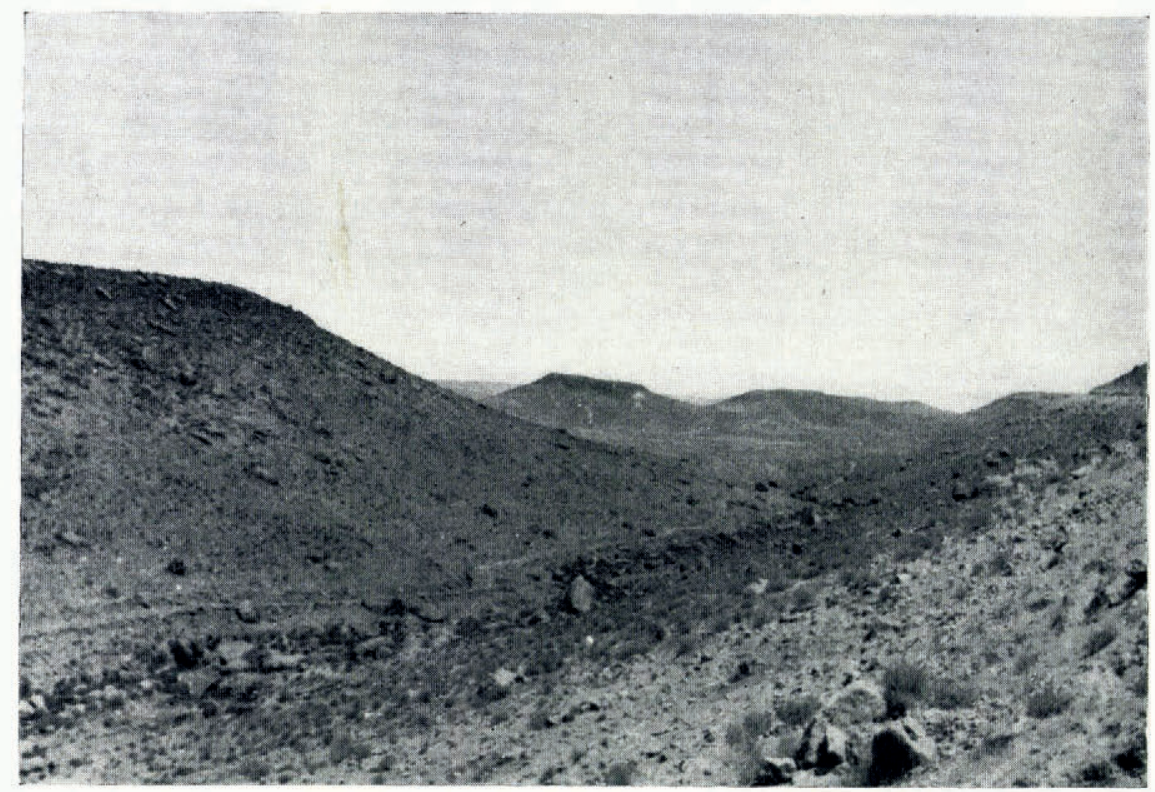

Fig. 5. The volcanic plateau of Pulhuanga at a height of 4 ,ooo m., showing a large depression with Riss moraines covered by Wiurm periglacial fans

This area primarily provided observations on periglacial phenomena. At the foot of Cerro Pulhuanga (at about 4, I0O m.), on one of the higher interfluves of the plateau the more resistant lavas have formed by congelifraction an excellent debris scree, the fragments of which have a maximum size of $5^{-6 \mathrm{~cm}}$. The debris occupies the hollows (Fig. 5) and preserves gullies on a steep slope. In nearby basins, at the foot of small rock outcrops, small angular stones formed by congelifraction fan out in a regular distribution and attain a thickness of as much as $2-3 \mathrm{~cm}$. They form successive strata several centimetres thick, composed of alternating coarse $\left(4^{-} 7 \mathrm{~cm}\right.$.) and fine (sands and gravels) debris. Their dip is regular at $7-8^{\circ}$ and sometimes more. Such formations also help to locate the former position of the firn line. These periglacial slopes are, of course, no longer active. As a result of having suffered frequent nocturnal frosts, they have disintegrated at the surface into a sandy, limonitic chocolatebrown soil, which is favourable to the Ichu grass covering all the solitary hills. Approaching the line of the valley, the terminations of the slopes have been cut by streams. They terminate on a low terrace, sections of which, produced by undermining of the steep river banks, show the 
encroachment in certain places of the thin fans onto the slope of the fluviatile formations. All these features suggest that the periglacial activity is related to the Würm glaciation.

However, these formations and the periglacial surface relief have added to the glacial landscape, which they almost completely obliterate. On the eastern side of this massif (at $3,700 \mathrm{~m}$.) the headwaters of streams flowing towards the Rio Lucanas have cut down to rocky barriers partially buried by recent periglacial material. Moreover, at about 4,00o $\mathrm{m}$. on this same plateau, basins eroded in the less resistant tuffs are lined by moraines which truncate the periglacial fans. Some of the accumulations, which are arranged arcuately and supported by rocky mounds, appear to form the remnants of partial down-cutting into the fans. Unfortunately, not every section can be examined. Nevertheless, in certain gullies these moraines can be seen clearly under the superficial gravels. They are earthy, little eroded, poor in pebbles and are composed of angular fragments. The blocks in them are not larger than $30 \mathrm{~cm}$. The action of melt waters there is partially obscured but beyond doubt, and there is some evidence of the action of running water particularly towards the summit. These deposits mark the beginning of the recession. This material is always weathered, and the granular rocks are often friable and even rotten. The ferruginous matrix is tinted orange with rust-coloured veinlets. In contrast, the overlying periglacial gravels are very fresh. They contain no friable rocks and are characterized by accumulations of iron oxides in the zone of fluctuating water table near the streams. It therefore appears that this area has not been glaciated since Riss times.

\section{Conclusions}

The following conclusions can be drawn from these observations:

(a) A certain transition can be observed, even in the interior of Peru, between the north and the south. In the north, the moraines show no action of melt waters and the conditions are similar to those of the Venezuelan Andes. The rhythm of melting was, as at present, essentially diurnal. The melt waters never achieved any importance as far as discharge is concerned. They were not capable of eroding the moraines accumulated at the extremities of the glaciers. This type of glacier was characterized by excessive terminal and lateral moraines, and by much reduced proglacial phenomena. These phenomena also occur in Venezuela at lat. $8-9^{\circ} \mathrm{N}$. but here at lat. $7^{\circ} \mathrm{S}$.

In the south, melt waters were more important. The moraines studied were essentially bottom moraines and the debris was transported by ice. In spite of the favourable surface relief, no terminal moraines of any great size were formed. Melting assumed a seasonal rhythm which is characteristic of tropical glaciers, as observed by Dollfus (1959) in the Lima area (lat. $12^{\circ} \mathrm{S}$.).

(b) The Riss glaciation was more active than the Würm glaciation, and this is in accordance with observations made by Dollfus and Tricart (1959) in the Lima area. It covered mountains, such as the Pulhuanga plateau, which had remained in the periglacial zone during Würm times. Elsewhere (as at Hualgayoc) the glacier tongues appear to have descended much lower, as is the case in regions of higher latitudes.

The firn line seems to have been a little lower during the Riss glaciation: at 4,000 $\mathrm{m}$. in lat. $\mathrm{I} 4{ }^{\circ} \mathrm{S}$. and at about $3,500 \mathrm{~m}$. in lat. $7^{\circ} \mathrm{S}$. The firn line at $4,000 \mathrm{~m}$. characterizes an area of glaciers already belonging to the tropical type, but glaciers at $3,500-3,600 \mathrm{~m}$. are of the equatorial type. The elevation of the firn line as the tropics are approached is a classic example. This elevation continues, with increased dryness, to the south of lat. $14^{\circ} \mathrm{S}$.

The Würm firn line varied during the cold period, as in Europe. At the time of the maximum (Würm I) it was at about 3,650 m., but later (Würm II ?) it had risen to 3,700 m. in the region of Hualgayoc. These altitudes governed the positions of the cirques, which were normally nourished by snow. They vary locally from the effects of accumulation by wind- 
drifting. On the eastern side of the Hualgayoc plateau the largest glaciers were nourished by drifting snow, blown by humid east winds from the Amazon. Although the altitudes are very similar, glaciation on the plateau was not so well developed on the western side. A similar asymmetry occurred in the Rio Lucanas region during the Riss glaciation.

The Würm firn line had the same general aspect as in Riss times. This, at approximately $3,650 \mathrm{~m}$. in Würm I near Hualgayoc, occurs between 4,300 and $4,400 \mathrm{~m}$. in lat. $\mathrm{I} 4^{\circ} \mathrm{S}$. At this altitude, in fact, small patches of snow are found clinging to the volcanic peaks. The difference in altitude of the firn line between lat. $7^{\circ}$ and $14^{\circ} \mathrm{S}$. would be about $700 \mathrm{~m}$. during Würm times, compared with $500 \mathrm{~m}$. during Riss times. In spite of the difficulty of making observations on the Würm firn line at Cerro Pulhuanga, this difference is far greater than any errors of determination. Thus, it seems that the elevation of the firn line in tropical latitudes was more accentuated in Würm and Holocene than during Riss times. If this is so, it is probable that the explanation lies in the distribution pattern of precipitation.

MS. received 30 June 1964

\section{REFERENCES}

Dollfus, O. 1959. Formes glaciaires et périglaciaires actuelles autour du lac Huampar (Andes centrales péruviennes). Bulletin de l'Association de Géographes Français, No. 286/7, p. 32-40.

Dollfus, O., and Tricart, J. 1959. Note sur les périodes froides dans les Andes péruviennes (région de la Oroya). Compte Rendu Sommaire des Séances de la Société Géologique de France, 1959, p. 236-38. 